\title{
Surface plasmon resonance effect of Ag nanoparticles for improving the photocatalytic performance of biochar quantum-dot $/ \mathrm{Bi}_{4} \mathrm{Ti}_{3} \mathrm{O}_{12}$ nanosheets
}

\author{
Tao Wang a,c, Xiqing Liu a,b, Qiuyue Men a,c, Changchang Ma a,c, , Yang Liu c,d, Wei Ma c,e, Zhi Liu c,f, \\ Maobin Wei c,d, Chunxiang Li a,c, Yongsheng Yan a,c,* \\ a School of Chemistry and Chemical Engineering, Jiangsu University, Zhenjiang 212013, Jiangsu, China \\ ${ }^{b}$ School of Material Science and Engineering, Jiangsu University, Zhenjiang 212013, Jiangsu, China \\ c Institute of Green Chemistry and Chemical Technology, Jiangsu University, Zhenjiang 212013, Jiangsu, China \\ ${ }^{d}$ College of Physics, Jilin Normal University, Siping 13600, Jilin, China \\ e Jiangsu United Chemical Co., Ltd., Zhenjiang 212212, Jiangsu, China \\ fSchool of Chemistry and Chemical Engineering, Liaoning Normal University, Dalian 116029, Liaoning, China
}

\section{A R T I C L E I N F}

\section{Article history:}

Received 6 December 2018

Accepted 8 February 2019

Published 5 June 2019

\section{Keywords:}

2D material

Plasmo resonance

Synergistic effect

Carbon quantum dot

Electron buffer

\section{A B S T R A C T}

Herein, we report a novel ternary material comprised of Ag nanoparticles and carbon quantum dots (CDs), which are co-loaded using 2D $\mathrm{Bi}_{4} \mathrm{Ti}_{3} \mathrm{O}_{12}$ (BIT) sheets. In this system, Ag can be applied as excited electron-hole pairs in the $\mathrm{Bi}_{4} \mathrm{Ti}_{3} \mathrm{O}_{12}$ by transferring the plasmonic energy from the metal to the semiconductor. The surface plasmon resonance of Ag can promote the electron transfer properties of the CDs, thereby improving the separation efficiency of the electron-hole pairs. Meanwhile, the CDs can act as an electron buffer to decrease the recombination rate of the electron hole. Moreover, CDs are prepared using a biomaterial, which can provide a chemical group to enhance the electron transfer and connection. The synergistic effects of CDs, Ag, and BIT enable the design of a photocatalytic application with a remarkably improved efficiency and operational stability.

(C) 2019, Dalian Institute of Chemical Physics, Chinese Academy of Sciences. Published by Elsevier B.V. All rights reserved.

\section{Introduction}

As is well known, an energy crisis and environmental pollution, among other prominent problems, are attracting increased attention [1-3]. To solve such issues, semiconductor-based photocatalysis has been considered an important investigative field because they can be used to remove environmental pollutants and can be applied to energy conversion through solar energy [4-6]. To date, numerous semiconductor photocatalysts have been explored, including $\mathrm{CdS}$ [7], $\mathrm{Ag}_{3} \mathrm{PO}_{4}$
[8], and CdSe [9]. However, their potential application has been limited owing to their corrosiveness, poor stability, and toxicity, as well as their low utilization of solar energy. Therefore, searching for high photocatalytic properties, stable, and environmentally-friendly materials has become important reference in photocatalysis.

Among such research areas, bismuth titanate $\left(\mathrm{Bi}_{4} \mathrm{Ti}_{3} \mathrm{O}_{12}\right.$, BIT) has been highly considered [10,11]. For example, Hou et al. [10] synthesized $\mathrm{Bi}_{4} \mathrm{Ti}_{3} \mathrm{O}_{12}$ nanofibers through a simple and economical technique of electrospinning combined with a sub-

\footnotetext{
* Corresponding author. Tel: +86-511-88791108; E-mail: yys@mail.ujs.edu.cn This work was financially supported by the National Natural Science Foundation of China (U1510126, 21676115), and the Natural Science Foundation of Jiangsu Provincial (BK20180884).

DOI: S1872-2067(19)63330-9 | http://www.sciencedirect.com/science/journal/18722067 | Chin. J. Catal., Vol. 40, No. 6, June 2019
} 
sequent calcination, and showed that the material exhibits an enhancement in both the visible-light driven photocatalytic decomposition of rhodamine (RhB) and a favorable recycling capability. Yao et al. [12] reported $\mathrm{Bi}_{4} \mathrm{Ti}_{3} \mathrm{O}_{12}$ prepared using a chemical solution decomposition (CSD) method, and evaluated the photocatalytic properties using photodegrade methyl orange (MO). In addition, the photocatalytic property of $\mathrm{Bi}_{4} \mathrm{Ti}_{3} \mathrm{O}_{12}$ has been predicted using the density functional theory (DFT) [13]. Nevertheless, certain problems, such as a low capacity for the separation of electron-hole pairs and low activity under the visible light region, still urgently need to be solved.

It is well known that noble metal nanoparticles loaded onto a semiconductor surface can extend the light-harvesting scope and produce more electron-hole pairs by virtue of a strong electromagnetic field formed through surface plasmon resonance (SPR) [14-16]. As one of the most efficient plasmonic materials, Ag has frequently been used as a catalyst by providing chemically active sites [17]. For example, Sun et al. [18] applied $\mathrm{Ag} / \mathrm{g}-\mathrm{C}_{3} \mathrm{~N}_{4}$ photocatalysts to remove $\mathrm{NO}_{x}$ under the illumination of visible light. $\mathrm{Li}$ et al. [19] reported a $\mathrm{Ag} / \mathrm{AgCl}$ decorated $\mathrm{Bi}_{4} \mathrm{Ti}_{3} \mathrm{O}_{12}$ nanosheet for an enhanced photocatalytic degradation of organic pollutants. Strong evidence has shown that Ag nanoparticles can cause an excellent photo response within the visible range owing to the SPR effects. Therefore, the utilization of SPR has provide a new idea to enhance the photocatalytic activity of $\mathrm{Bi}_{4} \mathrm{Ti}_{3} \mathrm{O}_{12}$.

Carbon quantum dots (CDs) are a recently discovered class of nanocarbons that exhibit abundant unique photophysical properties. In particular, an insoluble layer of CDs on the surface of a semiconductor can greatly enhance the structural stability and photocatalytic activity. For example, CDs/ $/ \mathrm{TiO}_{2}$ [20,21], CDs/BiWO 6 [22], CDs/CdS [23], and CDs/ZnO [24] have an improved photocatalytic activity and stability owing to the electron transfer, photoluminescence (PL), and electron reservoir properties of the CDs. In a previous report, CDs were synthesized from an organism, which is a greener and cheaper method, although the quantum efficiency is low.

Considering such remarkable yet defective properties of CDs, the SPR effect of Ag has been used to overcome such defects. Therefore, we propose a novel metal-CD semiconductor design as an efficient photocatalyst. In this work, we report a general program for the fabrication of $2 \mathrm{D} \mathrm{Ag} / \mathrm{CDs} / \mathrm{Bi}_{4} \mathrm{Ti}_{3} \mathrm{O}_{12}$, which exhibits a higher catalytic performance than bare $\mathrm{Bi}_{4} \mathrm{Ti}_{3} \mathrm{O}_{12}$ and $\mathrm{CDs} / \mathrm{Bi}_{4} \mathrm{Ti}_{3} \mathrm{O}_{12}$. Meanwhile, the synergistic effects of $\mathrm{CDs}$ and $\mathrm{Ag}$ particles in this system were investigated. Moreover, the mechanisms for the visible-light driven photocatalytic process on $2 \mathrm{D} \mathrm{Ag} / \mathrm{CDs} / \mathrm{Bi}_{4} \mathrm{Ti}_{3} \mathrm{O}_{12}$ composites were also investigated.

\section{Experimental}

\subsection{Preparation of $\mathrm{Bi}_{4} \mathrm{Ti}_{3} \mathrm{O}_{12}$ sheets}

The $\mathrm{Bi}_{4} \mathrm{Ti}_{3} \mathrm{O}_{12}$ sheets were synthesized using a molten salt method as reported in the literature [25]. Briefly, $\mathrm{Bi}_{2} \mathrm{O}_{3}, \mathrm{P} 25$, $\mathrm{KCl}$, and $\mathrm{NaCl}$ were mixed in logical order and amply grinded in an agate mortar. The mixture was then heated in a muffle fur- nace at $750{ }^{\circ} \mathrm{C}$ for $2 \mathrm{~h}$ in air. The obtained samples were washed with deionized water and ethanol three times, and then dried in an oven.

\subsection{Preparation of carbon dots and $\mathrm{CDs} / \mathrm{Bi}_{4} \mathrm{Ti}_{3} \mathrm{O}_{12}$ material}

CDs and CD/BIT materials were prepared using the hydrothermal treatment of bamboo powder in our previous investigation [26]. Briefly, $3 \mathrm{~g}$ of bamboo powder was added to $30 \mathrm{~mL}$ of deionized water. The mixture was then transferred into a Teflon-lined autoclave and heated at $200{ }^{\circ} \mathrm{C}$ for $12 \mathrm{~h}$. The CDs were collected through dialysis and freeze-drying. The CDs obtained were dispersed in water for further use.

Through a typical synthesis of CD-modified $\mathrm{Bi}_{4} \mathrm{Ti}_{3} \mathrm{O}_{12}$ materials [26], a certain amount of CDs was dissolved in $5 \mathrm{~mL}$ of ethanol and using ultrasonic dispersion. Then, $0.1 \mathrm{~g}$ of $\mathrm{Bi}_{4} \mathrm{Ti}_{3} \mathrm{O}_{12}$ was added into the above solution and magnetically stirred at room temperature. After being stirred for $12 \mathrm{~h}$, the suspension was heated at $60{ }^{\circ} \mathrm{C}$ to evaporate the water. The dried composite was heated at $200{ }^{\circ} \mathrm{C}$ for $1 \mathrm{~h}$ in a $\mathrm{N}_{2}$ atmosphere. The optimum CD/BIT composites were prepared based on a previous study [26].

\subsection{Preparation of $2 \mathrm{D} \mathrm{Ag} / \mathrm{CDs} / \mathrm{Bi}_{4} \mathrm{Ti}_{3} \mathrm{O}_{12}$ composites}

The characteristic processing of $\mathrm{Ag} / \mathrm{CDs} / \mathrm{Bi}_{4} \mathrm{Ti}_{3} \mathrm{O}_{12}$ is as follows. $\mathrm{CDs} / \mathrm{Bi}_{4} \mathrm{Ti}_{3} \mathrm{O}_{12}$ sheets $(0.1 \mathrm{~g})$ were dispersed in $30 \mathrm{~mL}$ of water, and a suitable amount of aqueous $\mathrm{AgNO}_{3}(1 \mathrm{mg} / \mathrm{mL})$ was added to the suspension. The mixture was then transferred to a quartz reaction flask with vigorous stirring and irradiated under a UV lamp for $30 \mathrm{~min}$. Finally, the $\mathrm{Ag} / \mathrm{CDs} / \mathrm{Bi}_{4} \mathrm{Ti}_{3} \mathrm{O}_{12}$ samples obtained were washed thoroughly with deionized water and ethanol several times and dried. To investigate the influence of the amount of Ag deposition on the photocatalytic activity, a series of $\mathrm{Ag} / \mathrm{CDs} / \mathrm{Bi}_{4} \mathrm{Ti}_{3} \mathrm{O}_{12}$ samples with different mass percentages of $\mathrm{Ag}$ were prepared, which can be written as 2D Ag/CD/BIT-1, Ag/CD/BIT-2, Ag/CD/BIT-3, Ag/CD/BIT-4, and $\mathrm{Ag} / \mathrm{CD} / \mathrm{BIT}-5$, respectively.

\subsection{Photocatalytic activity measurement}

The photocatalyst degradation of the different as-prepared materials was evaluated by decomposing tetracycline (TC) under a $300 \mathrm{~W}$ Xenon irradiation lamp with a filter cutting off $400 \mathrm{~nm}$ light. During every experiment, a $50 \mathrm{mg}$ photocatalyst was added to a $100 \mathrm{~mL} 10 \mathrm{mg} / \mathrm{L}$ TC solution. The simple process is as follows. The mixture was first stirred under dark conditions for $30 \mathrm{~min}$ to obtain the adsorption/desorption equilibrium between the TC and samples. Next, the mixture was irradiation with light, and a $4 \mathrm{~mL}$ solution suspension was obtained every $10 \mathrm{~min}$, and the solid samples were removed. The TC concentration in the filtrate was detected using a UV-Vis spectrophotometer. The efficiencies $(W)$ toward TC degradation over the different materials were calculated through equation $W=1-C_{t} / C_{0}$, where $C_{0}$ is the concentration of the solution suspension when the adsorption/desorption equilibrium was determined, and $C_{t}$ is the solution concentration at time $t$. 


\subsection{Physical and chemical characterization}

X-ray diffraction patterns (XRD) of the samples were recorded at room temperature, and the patterns of the photocatalyst were obtained using a D/max-RA X-ray diffractometer (Rigaku, Japan) equipped with Ni-filtrated $\mathrm{Cu} K_{\alpha}$ radiation (40 $\mathrm{kV}, 200 \mathrm{~mA}$ ) at $10^{\circ}-80^{\circ}$ with a scanning step of $7^{\circ} / \mathrm{min}$. An $\mathrm{X}$-ray photoelectron spectroscopy (XPS) analysis was measured on an American electronics physical HI5700ESCA system with an X-ray photoelectron spectroscope using $\mathrm{Al} K(1486.6 \mathrm{eV})$ monochromatic X-ray radiation. The peak positions were corrected against the $\mathrm{C} 1 \mathrm{~s}$ peak $(284.6 \mathrm{eV})$ of the contaminated carbon. The infrared spectra were obtained on a Nicolet Magna-IR 550 Fourier transform infrared (FT-IR) spectrometer, and $\mathrm{KBr}$ was used as the reference sample within the wavelength range of 400-4000 $\mathrm{cm}^{-1}$. The transmission electron microscope (TEM) images were examined using JEM-2100 transmission electron microscopy (JEOL, Japan). Scanning electron microscopy (SEM) images were recorded using field emission scanning electron microscopy (Nova Nano SEM 450, FEI). The room-temperature photoluminescence (PL) spectra were investigated utilizing a Cary Eclipse Spectrophotometer (VARIAN, USA) equipped with a xenon (Xe) lamp with an excitation wavelength of $325 \mathrm{~nm}$. UV-vis diffuse reflectance spectra (DRS) were obtained using a Shimadzu UV-3600 spectrometer by applying $\mathrm{BaSO}_{4}$ as a reference. The UV-vis absorption spectra of the samples were measured on a Cary 5000 (Agilent, USA) UV-Vis spectrophotometer. The electrochemical measurements were carried out on a VersaSTAT3 (Princeton, Inc.) electrochemical workstation in a three-electrode system with a platinum network counter electrode and an $\mathrm{Ag} / \mathrm{AgCl}$ (saturated $\mathrm{KCl}$ ) reference electrode, using a $0.5 \mathrm{~mol} / \mathrm{L}$ concentration of $\mathrm{Na}_{2} \mathrm{SO}_{4}$ aqueous electrolyte under ambient temperature (25 $\left.{ }^{\circ} \mathrm{C}\right)$. The transient photocurrent response was determined on an electrochemical analyzer using a $0.5 \mathrm{~V}$ bias voltage under light irradiation ( $300 \mathrm{~W}$ Xe lamp as the light source).

\section{Results and discussion}

\subsection{XRD analysis}

The XRD patterns of BIT, CD/BIT, and Ag/CD/BIT composites are shown in Fig. 1. The main characteristic diffraction peaks of BIT, CD/BIT, and Ag/CD/BIT composites can be indexed to $\mathrm{Bi}_{4} \mathrm{Ti}_{3} \mathrm{O}_{12}$ crystal domains (PDF \#35-0795). The XRD patterns of the CD/BIT and Ag/CD/BIT samples implied that the crystal phase of $\mathrm{Bi}_{4} \mathrm{Ti}_{3} \mathrm{O}_{12}$ did not change with the loading of $\mathrm{CDs}$ and $\mathrm{Ag}$ nanoparticles on the $\mathrm{Bi}_{4} \mathrm{Ti}_{3} \mathrm{O}_{12}$ surface. However, no clear signal attributable to the CDs and Ag could be observed in the $\mathrm{CD} / \mathrm{BIT}$ and $\mathrm{Ag} / \mathrm{CD} / \mathrm{BIT}$ composites, which may be due to the low content, as well as the good dispersion on the sheets [27]. However, the peak intensities in the CD/BIT and $\mathrm{Ag} / \mathrm{CD} / \mathrm{BIT}$ composites were suppressed, suggesting the influence of CDs and $\mathrm{Ag}$ on the crystallite structure. In addition, the formation of a $\mathrm{O}=\mathrm{C}-\mathrm{O}-\mathrm{Ag}$ bond can also affect the peak intensity [28]. It was clearly observed that the sample CDs and $\mathrm{Ag}$ nanoparticles did not change the crystal phase of the $\mathrm{Bi}_{4} \mathrm{Ti}_{3} \mathrm{O}_{12}$,

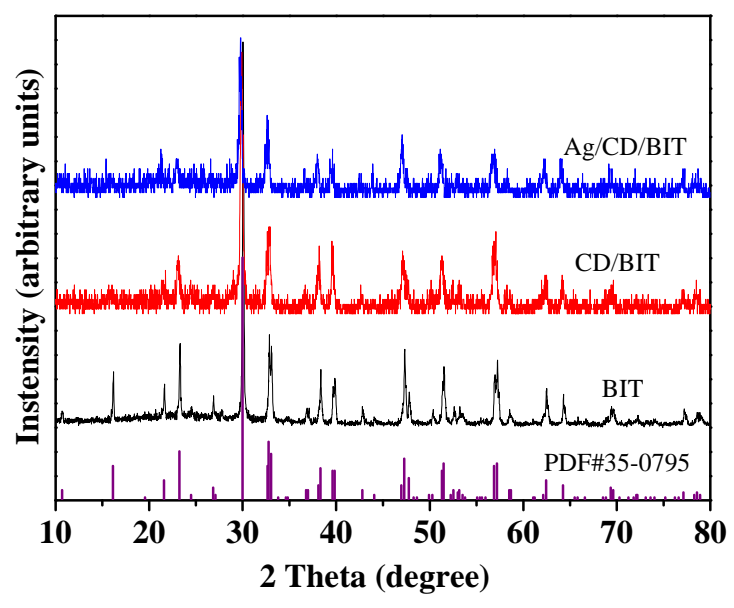

Fig. 1. XRD patterns of pure BIT, CD/BIT, and 2D Ag/CD/BIT composites.

which was further demonstrated through the following characterizations.

\subsection{XPS analysis}

To understand the interactions, the XPS technique was applied to confirm the specific surface composition and element status. Fig. 2a shows the survey spectrum of the 2D $\mathrm{Ag} / \mathrm{CD} / \mathrm{BIT}-3$ material, revealing that the hybrid was mainly composed of $\mathrm{Ag}, \mathrm{C}, \mathrm{Bi}, \mathrm{Ti}$, and $\mathrm{O}$ elements. The XPS signals of $\mathrm{Bi}$ can be attributed to $\mathrm{Bi} 4 f_{5 / 2}$ and $\mathrm{Bi} 4 f_{7 / 2}$, respectively (Fig. $2 \mathrm{~b}$ ). The two peaks were ascribed to $\mathrm{Bi}^{3+}$ which is consistent with the $\mathrm{Bi}_{2} \mathrm{O}_{3}$ [29]. The peaks of Ti can be ascribed to Ti $2 p_{1 / 2}$ and Ti $2 p_{3 / 2}$, which agree with $\mathrm{TiO}_{2}$ (Fig. 2c) [30]. Moreover, the XPS spectrum of the $01 s$ is as shown in Fig. $2 \mathrm{~d}$, the major peak at $529.4 \mathrm{eV}$ was assigned to the oxygen in the BIT lattice, and the peak at $531.6 \mathrm{eV}$ was related to the surface-adsorbed oxygen on the BIT [26]. Meanwhile, the peaks of C $1 s$ assigned to the $\mathrm{C}-\mathrm{C} s p^{2}$-hybridized carbon of CDs, C-O, and $\mathrm{COO}$ bands with the binding energy of a C 1 s orbit were centered at 284.6, 285.4, and $288.4 \mathrm{eV}$, respectively (Fig. 2e) [31]. The $\mathrm{C}-\mathrm{O}$ band can enhance the bond between the BIT and CDs for speeding up the electronic transfer. The strongly shaken-up satellite doublet of $\mathrm{Ag} 3 d$ was identified as $\mathrm{Ag} 3 d_{5 / 2}$ and $\mathrm{Ag} 3 d_{3 / 2}$ orbits attributed to the Ag nanoparticles (Fig. 2f). Moreover, as reported in [29], the groups of $\mathrm{COO}$ can combine the $\mathrm{Ag}$ ions into $\mathrm{O}=\mathrm{C}-\mathrm{O}-\mathrm{Ag}$ groups, which may be the key to the electronic transfer and increased stability of the sample. The results indicate that the 2D Ag/CD/BIT materials were successfully and stably synthesized, which was proven through the recycling experiments.

\subsection{SEM and TEM analysis}

To study the morphology and structure of the as-prepared materials, SEM and TEM images were provided [32]. The SEM images in Fig. S1 (see Supporting Information) show the sheet-like shape of BIT, CD/BIT, and 2D Ag/CD/BIT-3, respectively. From the SEM images, we cannot find any changes on the 

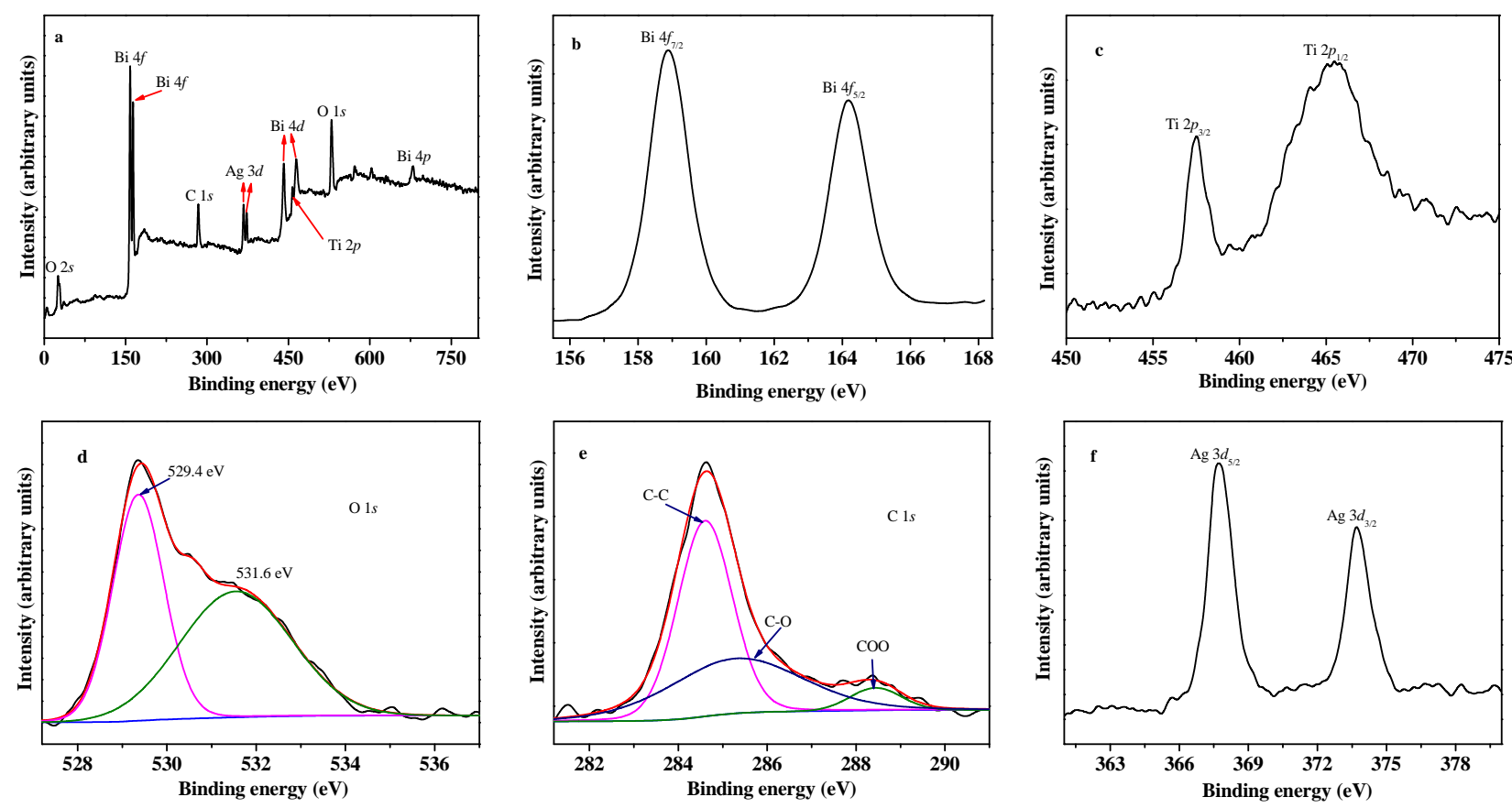

Fig. 2. (a) XPS spectrum of the $2 \mathrm{D}$ Ag/CD/BIT composites; High resolution XPS spectra of (b) Bi $4 f$, (c) Ti $2 p$, (d) $01 s$, (e) C $1 s$, and (f) Ag $3 d$ of the $2 \mathrm{D}$ $\mathrm{Ag} / \mathrm{CD} / \mathrm{BIT}$.

surface, which may be attributed to the low size and contents of the CDs and Ag nanoparticles, as reported in Ref. [33]. However, many small pieces are shown in Fig. S1b, which may be due to the ultrasonic characteristics. The elemental composition of the 2D Ag/CD/BIT-3 sample was analyzed using energy dispersive X-ray spectroscopy (EDS), and as shown in Fig. S2b-f, the EDS mapping revealed that bismuth, titanium, oxygen, carbon, and sliver were present and well distributed in the sheet. The 2D Ag/CD/BIT-3 composite was further observed using TEM and HRTEM. As shown in Fig. S1c, the sample was a clear visual sheet, and it was difficult to find the Ag nanoparticles and CDs owing to their small size. Moreover, the HRTEM image in

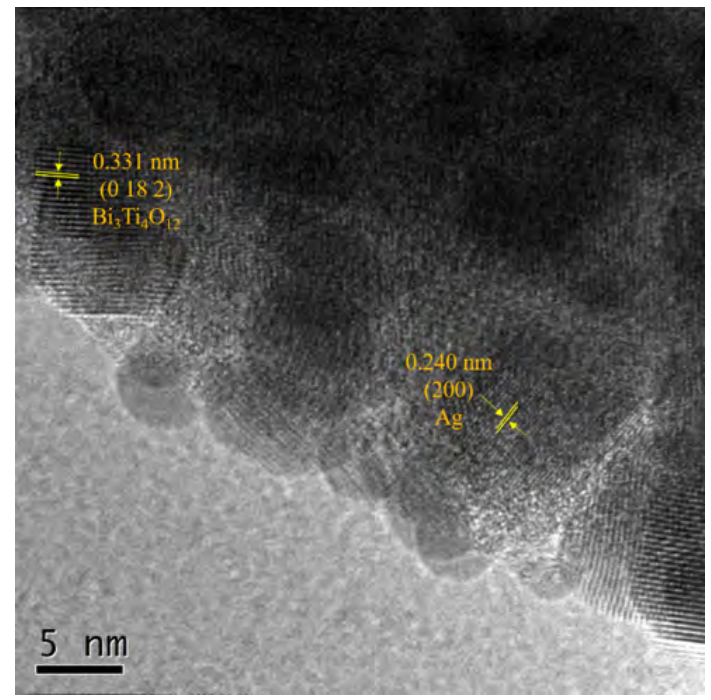

Fig. 3. HRTEM images of the $\mathrm{Ag} / \mathrm{CD} / \mathrm{BIT}$ composites.
Fig. 3 shows two different lattice fringes at 0.331 and $0.240 \mathrm{~nm}$, which agree well with the (0 18 2) plane of BIT and the (200) plane of Ag, respectively [34]. However, the lattice fringes of the CDs were hard to find owing to the low content and complex lattice, which is consistent with a previous report [26]. The EDS mapping and XPS indicate that the CDs existed in the 2D Ag/CD/BIT composites.

\subsection{Optical analysis}

Fig. 4a shows the PL spectra of BIT, CD/BIT, and 2D $\mathrm{Ag} / \mathrm{CD} / \mathrm{BIT}$ with an intense fluorescence emission peak at 360 $\mathrm{nm}$. As can be clearly seen, based on a comparison of the highest PL peak of bare BIT, the intensity of CD/BIT was decreased, indicating that the recombination of photo-induced electrons-holes achieved an efficient separation after a suitable amount of CD loading [35,36]. This result demonstrated that the CDs acted as both electron donors and electron acceptors $[37,38]$. Moreover, the intensity of 2D Ag/CD/BIT was comparatively lower than the former two, which confirmed that the photoelectrons were speedily transferred through an interface to promote the carrier separation because of the SPR effect of $\mathrm{Ag}$ and the unique photophysical properties of the CDs. Therefore, a 2D Ag/CD/BIT hybrid exhibited an excellent photocatalytic activity.

The UV-vis diffuse reflectance spectra (DRS) of BIT, CD/BIT, and 2D Ag/CD/BIT are shown in Fig. 4b. The pure BIT showed an absorption edge at ca. $400 \mathrm{~nm}$ [39]. When loaded with CDs, the absorption edge displayed a red-shift compared to bare BIT, suggesting that the CDs can expand the spectral responsive range of visible light. Moreover, an intense visible-light absorp- 

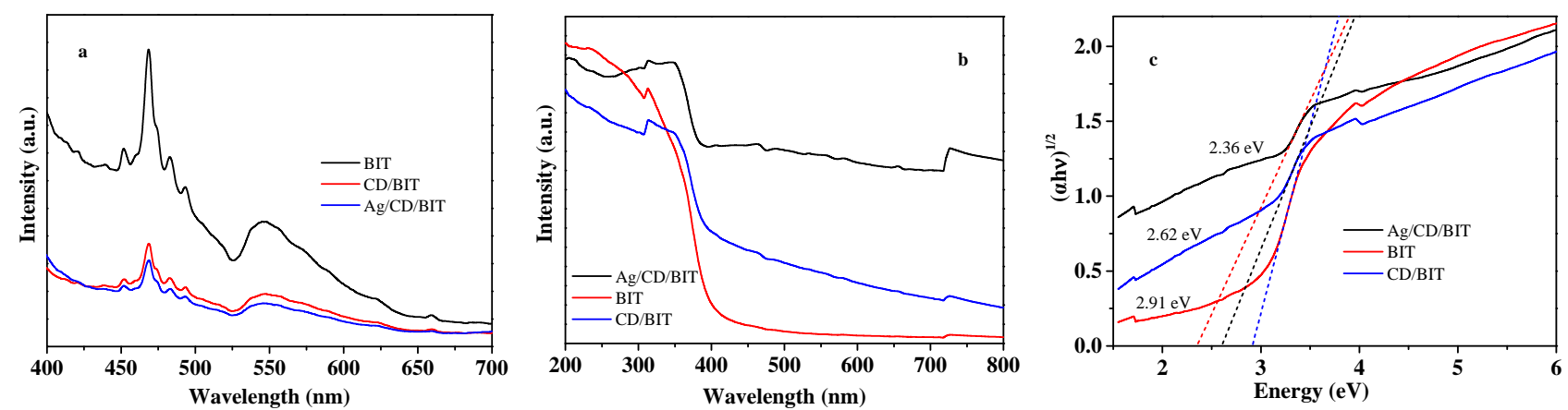

Fig. 4. (a) PL spectra, (b) UV-vis diffuse reflectance spectra, and (c) (E-photon) $)^{2}$ vs. $E$-photon curves for the bare BIT, CD/BIT and 2D Ag/CD/BIT.

tion was seen through the introduction of Ag, which may be attributed to the localized SPR effect of the Ag [40]. Meanwhile, the band gap energy $\left(E_{\mathrm{g}}\right)$ of the samples can be calculated from the DRS data based on the Kubelka-Munk function $(\alpha h v=A(h v$ - $E \mathrm{~g})^{n / 2}$ ). Here, $\alpha, h, A$, and $v$ represent the absorption coefficient, Planck constant, a constant, and the optical frequency, respectively. The value of $n$ is dependent on the type of electronic transition ( $n=1$ for a direct band-gap, and 4 for an indirect band-gap). For a $\mathrm{Bi}_{4} \mathrm{Ti}_{3} \mathrm{O}_{12}$ based semiconductor, $n$ was 1 for a direct band-gap [41]. Therefore, the band-gaps of BIT, $\mathrm{CD} / \mathrm{BIT}$, and Ag/CD/BIT were determined to be 2.91, 2.62, and $2.36 \mathrm{eV}$, respectively (Fig. 4c). A narrower band-gap can extend the absorption of the solar spectrum range and thus improve the photogeneration of the electron-hole pairs [42]. These phenomena may be attributed to the visible-light absorption capacity of the CDs and the SPR effect of the Ag nanoparticles, which improved the photocatalytic activity of the 2D $\mathrm{Ag} / \mathrm{CD} / \mathrm{BIT}$ composites.

\subsection{Electrochemical properties}

An electrochemistry analysis was applied to explain the separation, migration, and trapping of the photogenerated charge carriers $[43,44]$. As shown in Fig. 5a, it was clear that $\mathrm{CD} / \mathrm{BIT}$ exhibited a relatively higher photocurrent density than the bare BIT. Because a photocurrent is derived from the migration of electrons to the back contact under light irradiation, the results indicate that the introduction of CDs was in favor of photoelectron generation and transport [45]. As was particularly clear, 2D Ag/CD/BIT displayed a much stronger photocurrent intensity, confirming that the synergistic effect of the CDs and Ag separates the photogenerated electron-hole pairs more efficiently, enhancing the separation. The results coincide with the PL spectra and photocatalytic activity.

EIS Nyquist plots further acted as corroborative evidence for learning the interfacial charge transfer behavior of BIT, CD/BIT, and 2D Ag/CD/BIT photoelectrodes (Fig. 5b). As is well known, a smaller diameter means a weaker impedance and more efficient charge transfer [46]. The 2D Ag/CD/BIT composites showed the smallest diameter among the samples, which suggests that the addition of CDs and Ag can promote the interfacial charge transfer and photocatalytic behavior.

\subsection{FT-IR analysis}

The possible interactions among the 2D Ag/CD/BIT sheets were further proved using FT-IR spectra. The FT-IR was used to determine the change in functional groups during the synthesis process. The bands at 577 and $817 \mathrm{~cm}^{-1}$ in BIT were ascribed to the stretching vibrations of Ti-O and $\mathrm{Bi}-\mathrm{O}$. As shown in Fig. 6, the stretching vibrations of $\mathrm{Ti}-\mathrm{O}$ and $\mathrm{Bi}-\mathrm{O}$ can clearly be seen in both $\mathrm{CD} / \mathrm{BIT}$ and $2 \mathrm{D} \mathrm{Ag/CD/BIT} \mathrm{samples,} \mathrm{respec-}$ tively [47]. Compared with pure BIT, there was no change in the $\mathrm{CD} / \mathrm{BIT}$ and $2 \mathrm{D} \mathrm{Ag} / \mathrm{CD} / \mathrm{BIT}$ contract with pure BIT, indi-
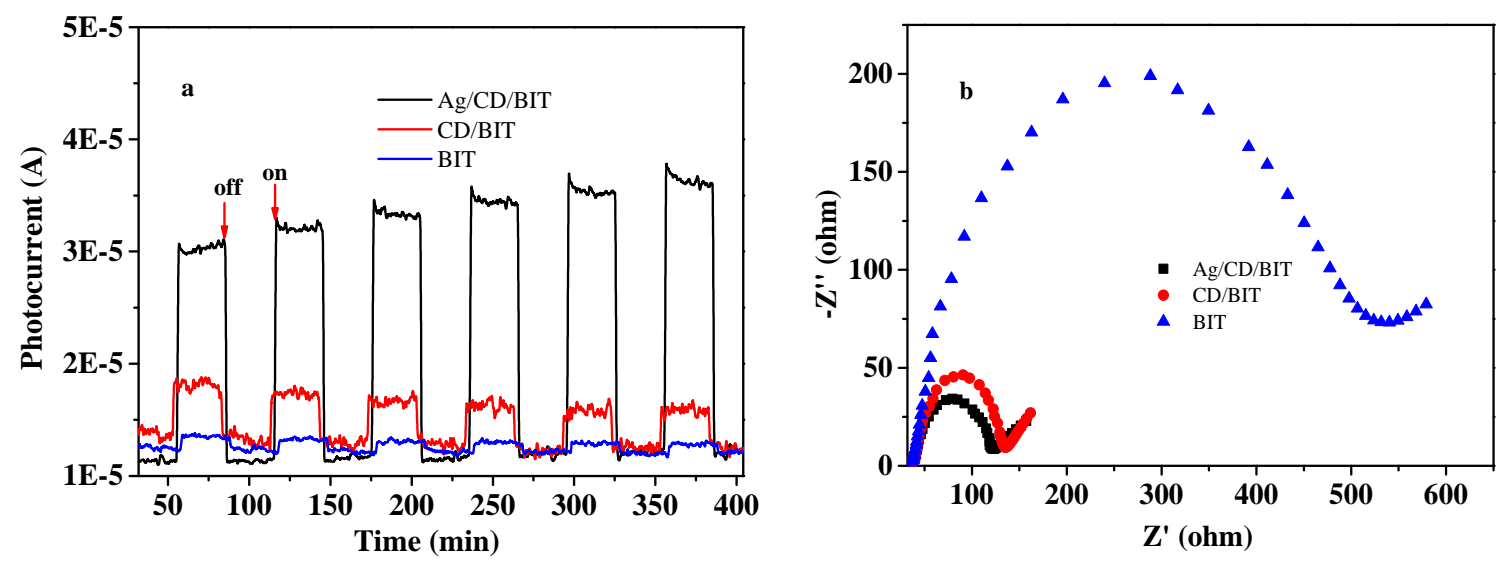

Fig. 5. (a) Transient photocurrent response and (b) electrochemical impedance spectroscopy (EIS) of pure BIT, CD/BIT, and 2D Ag/CD/BIT. 


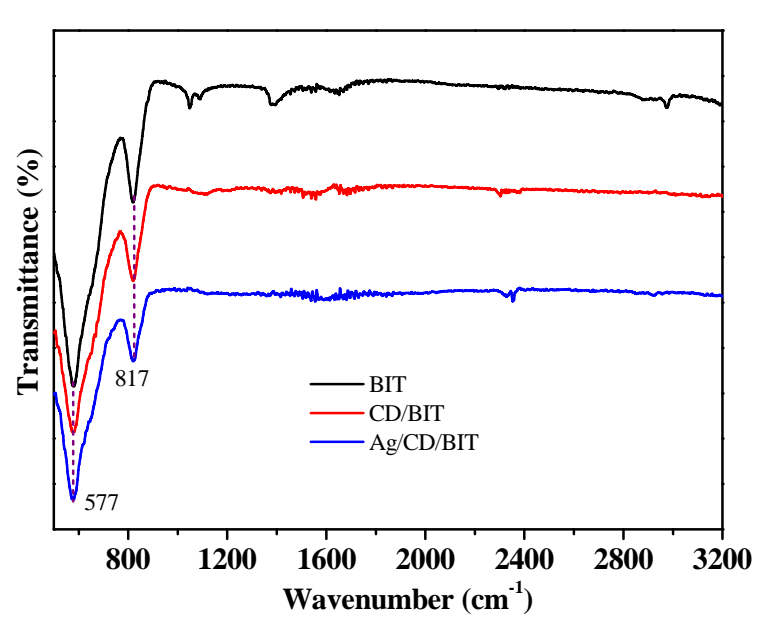

Fig. 6. FT-IR spectra of bare BIT, CD/BIT, and 2D Ag/CD/BIT samples.

cating that the CDs and Ag did not change the structure of the BIT. Meanwhile, we cannot find any peaks for Ag and CDs, which may be attributed to the low content. The analysis results were in accord with the XRD results. In general, the BET-specific surface area of the photocatalyst was an important factor in which a bigger surface area could provide more active sites, thereby enhancing the photocatalytic activity; however, in this system we did not provide data on the surface area, which was attributed to the Ag and CDs being unable to change the surface area of the BIT sheet owing to the low content and smaller size, as reported in Ref. [48].

\subsection{Photocatalytic performance}

The interfacial charge transfer of the as-prepared samples and its influence on the visible light degradation of tetracycline (TC) were studied in detail. Fig. 7a shows the variation in the concentration ration versus the irradiation time in a series of 2D Ag/CD/BIT samples. All 2D Ag/CD/BIT samples displayed an excellent photocatalytic activity, among which 2D Ag/CD/BIT-3 showed the optimum degradation effect, which suggests the best proportion of the 2D Ag/CD/BIT-3 sample. These results proved that the Ag and CDs really can enhance the photocatalytic activity, which is mainly attributed to the excellent charge transfer and extend light absorption [49,50]. Meanwhile, compared with the bare BIT and CD/BIT photocatalyst, 2D Ag/CD/BIT still exhibited higher degradation efficiencies, demonstrating that Ag played a critical role in the enhancement of the photocatalytic activity (Fig. 7b). As expected, the SPR effect can further improve the photocatalytic activity of a CD/BIT sample. Furthermore, the dynamics were also studied, and the optimum samples of $2 \mathrm{D} \mathrm{Ag/CD/BIT} \mathrm{exhibited} \mathrm{a} k$ value of $0.01899 \mathrm{~min}^{-1}$, which was higher than the samples of CD/BIT (0.01092 $\left.\mathrm{min}^{-1}\right)$ and BIT (0.00191 min-1) (Fig. 7c). The enhanced activity of the $2 \mathrm{D} \mathrm{Ag} / \mathrm{CD} / \mathrm{BIT}$ may be attributed to the optical properties of the CDs, and the SPR effect of the Ag. The SPR effect of Ag could further improve the activity of the $\mathrm{CD} / \mathrm{BIT}$, which is due to the synergistic effect of the charge transfer and hot electrons over the CDs and Ag nanoparticles [51].

\subsection{Radical tapping experiments and stabilities}

To investigate the main highly active reactors generated that are responsible for the visible-light driven photocatalytic process, the experiments were conducted in the presence of 1,4-benzoquinone (BQ, a scavenger for $\cdot \mathrm{O}_{2}{ }^{-}$), isopropanol (IPA, a scavenger for $\cdot \mathrm{OH}$ ), and EDTA disodium salt (EDTA-2Na, a scavenger for $\mathrm{h}^{+}$) $[52,53]$. The results showed that the degradation efficiency of TC significantly decreased in the presence of BQ and IPA. When EDTA-2Na was added to the reaction system, it only affected the degradation efficiency slightly (Fig. 8a). It can be concluded that $\cdot \mathrm{O}_{2}^{-}$and $\mathrm{h}^{+}$were the major reactive species, and $\cdot \mathrm{OH}$ was also involved but not distinct $[54,55]$.

Furthermore, the photocatalytic stabilities of 2D Ag/CD/BIT were explored through recycling experiments (Fig. 8b). The pollutant was bleached after every TC decomposition experiment, and the 2D Ag/CD/BIT sample was sufficiently stale after the repeated experiments without exposure and without an obvious loss of the photocatalytic ratio. Therefore, the 2D $\mathrm{Ag} / \mathrm{CD} / \mathrm{BIT}$ sample can be used as an effective material with good stability.

\subsection{Possible photocatalytic mechanism}

Based on the analysis discussed above, a possible photocatalytic mechanism was proposed for the $2 \mathrm{D} \mathrm{Ag} / \mathrm{CD} / \mathrm{BIT}$ ma-
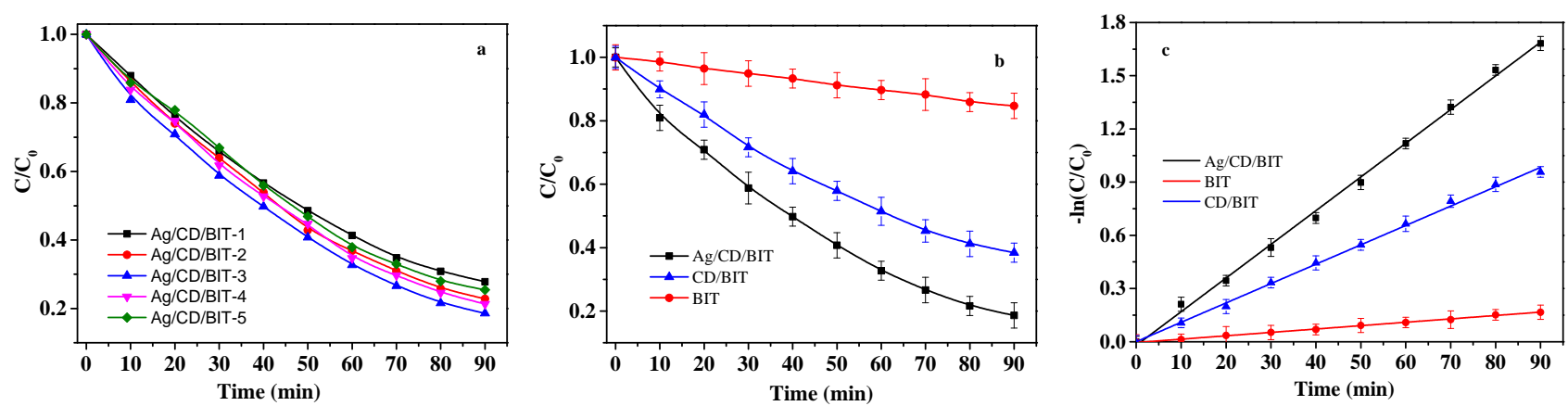

Fig. 7. (a) Photocatalytic activities for different ratios of Ag/CD/BIT composites; (b) Photocatalytic activity of pure BIT, CD/BIT, and 2D Ag/CD/BIT-3 samples; (c) The corresponding kinetic fit. 

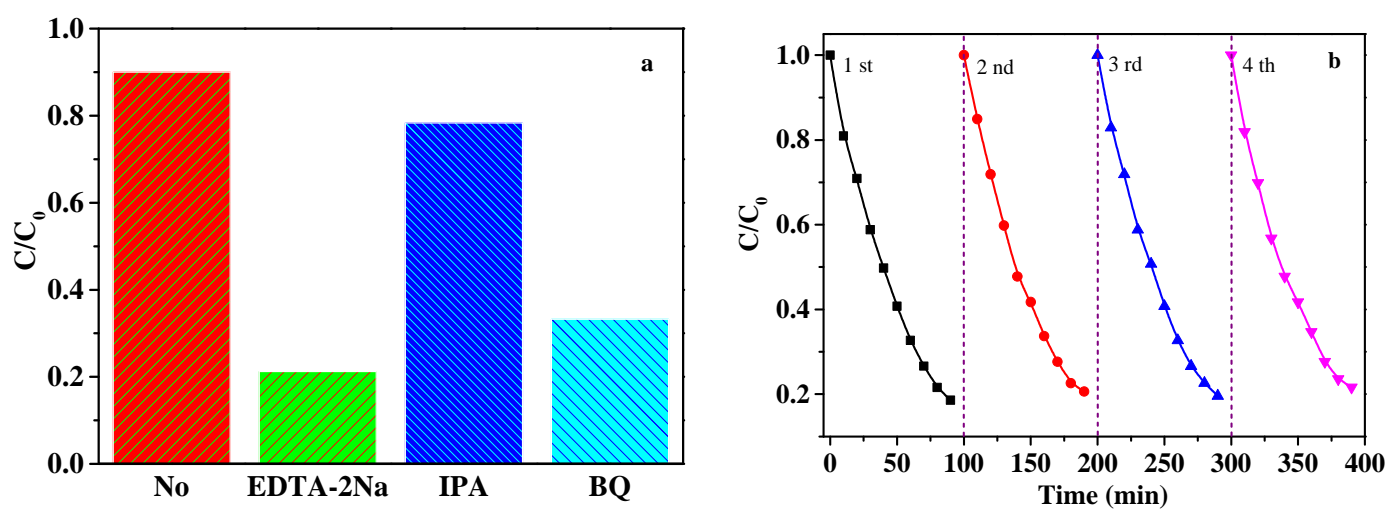

Fig. 8. (a) Comparison of photocatalytic activities over 2D Ag/CD/BIT-3 composites with or without the addition of capture agents; (b) Cycling runs for the photocatalytic activity with $2 \mathrm{D} \mathrm{Ag/CD/BIT-3}$ catalyst for four cycles for $400 \mathrm{~min}$.

terials, as shown in Fig. 9. The CDs, Ag nanoparticles, and synergistic effect among each component play multiple vital roles in such a system. Under visible light illumination, the BIT absorbed photons to produce electron-hole pairs. Under the influence of SPR effect-induced strong local electromagnetic fields, Ag nanoparticles could aid the system in capturing photons, and thus the formation speed of the electron-hole pairs [56]. At the same time, the SPR effect of the Ag nanoparticles could further promote the light-harvesting capacity of the CDs and excited semiconductor. In this system, the CDs acted as an electron reservoir and transporter to accumulate electrons for the accelerating charge separation. Meanwhile, the results of the UV-vis spectra demonstrated that the CDs and Ag could extend the light absorption [57]. Based on the above, an efficient separation of the electron-hole pairs was enhanced at the interface of the $\mathrm{Ag} / \mathrm{CD} / \mathrm{BIT}$ composites. The $\mathrm{e}^{-}$migrated from the conduction band (CB) of BIT to the Ag and CDs directly. In other words, the $\mathrm{e}^{-}$in the CDs would continue to migrate to the Ag. The electrons then reacted with oxygen to form $\bullet^{\circ} \mathrm{O}^{-}$, and the holes produced $\bullet \mathrm{OH}$ with $\mathrm{H}_{2} \mathrm{O} / \mathrm{OH}^{-}$, which is consistent with related reports [58]. Therefore, the synergistic effect of BIT, CDs, and Ag nanoparticles effectively enhanced the absorption, improving the photocatalytic activity.

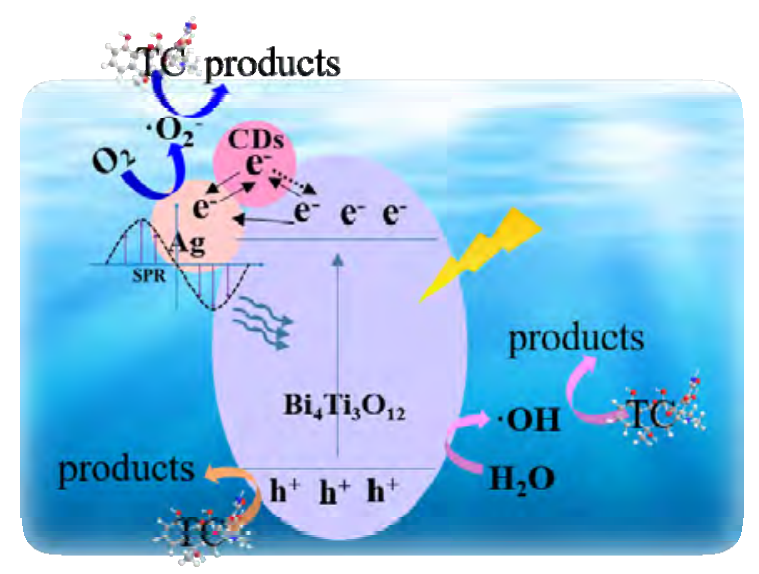

Fig. 9. Proposed reaction mechanism for visible-light driven on $\mathrm{Ag} / \mathrm{CD} / \mathrm{BIT}$ nanosheets.

\section{Conclusions}

In summary, a highly efficient 2D complex photocatalyst (2D $\mathrm{Ag} / \mathrm{CD} / \mathrm{BIT}$ ) was fabricated by combining the photoinduced electron-transfer properties of CDs, the SPR effect of Ag, and a semiconductor of BIT. The synergistic effects of CDs, Ag, and BIT lead to a degradation of pollutants. In the present system, the electrons on BIT can quickly transfer to the surface of the $\mathrm{Ag}$ nanoparticles and increase the amount of active species, thereby enhancing the photocatalytic activity. Here, the designed nanostructured materials achieved an excellent photocatalytic activity and electron migrated capacity. These findings may provide a new strategy for the preparation of new materials for energy sources and the environment.

\section{Acknowledgments}

This work was financially supported by the National Natural Science Foundation of China (U1510126, 21676115), and the Natural Science Foundation of Jiangsu Provincial (BK20180884).

\section{References}

[1] Y. Jin, S. Wu, Z. Zeng, Z. Fu, Environ. Pollut., 2017, 222, 1-9.

[2] A. J. Cramer, J. M. Cole, J. Mater. Chem. A, 2017, 5, 10746-10771.

[3] Y. P. Wang, Q. Fu, C. Li, H. H. Li, H. Tang, ACS Sustainable Chem. Eng., 2018, 6, 15083-15091.

[4] X. Meng, L. Liu, S. Ouyang, H. Xu, D. Wang, N. Zhao, J. Ye, Adv. Mater., 2016, 28, 6781-6803.

[5] X. Zhang, X. Li, D. Zhang, N.Q. Su, W. Yang, H.O. Everitt, J. Liu, Nat. Commun., 2017, 8, 14542.

[6] H. Yu, W. Liu, X. Wang, F. Wang, Appl. Catal. B, 2018, 225, 415-423.

[7] K. M. Cho, K. H. Kim, K. Park, C. Kim, S. Kim, A. Alsaggaf, I. Gereige, H. T. Jung, ACS Catal., 2017, 10, 7064-7069.

[8] K. J. Yun, I. Y. Kim, J. M. Lee, S. Nahm, J. W. Choi, S. J. Hwang, Mater. Lett., 2014, 114, 152-155.

[9] F. Qiu, Z. Han, J. J. Peterson, M. Y. Odoi, K. L. Sowers, T. D. Krauss, Nano Lett., 2016, 16, 5347-5352.

[10] D. Hou, W. Luo, Y. Huang, J. C. Yu, X. Hu, Nanoscale, 2013, 5, 


\section{Graphical Abstract}

Chin. J. Catal., 2019, 40: 886-894 doi: S1872-2067(19)63330-9

Surface plasmon resonance effect of Ag nanoparticles for improving the photocatalytic performance of biochar quantum-dot/ $\mathrm{Bi}_{4} \mathrm{Ti}_{3} \mathrm{O}_{12}$ nanosheets

Tao Wang, Xiqing Liu, Qiuyue Men, Changchang Ma *, Yang Liu, Wei Ma, Zhi Liu, Maobin Wei, Chunxiang Li, Yongsheng Yan* Jiangsu University; Jilin Normal University; Jiangsu United Chemical Co., Ltd.; Liaoning Normal University

The synergistic effects of CDs, Ag, and BIT enabled the design for a photocatalytic application with a remarkably improved efficiency and operational stability.

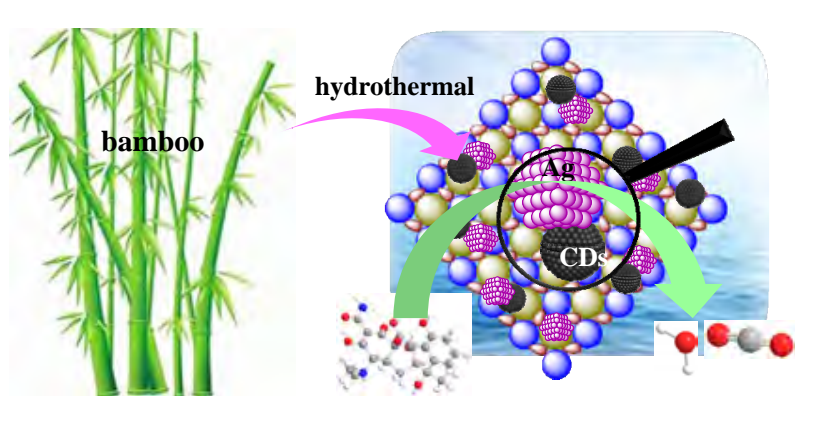

2028-2035.

[11] Z. Chen, H. Jiang, W. Jin, C. Shi, Appl. Catal. B, 2016, 180, 698-706.

[12] W. F. Yao, X. H. Xu, H. Wang, J. T. Zhou, X. N. Yang, Y. Zhang, S. X. Shang, B. B. Huang, Appl. Catal. B, 2004, 52, 109-116.

[13] S. Murugesan, M. N. Huda, Y. Yan, M. M. Al-Jassim, V. Subramanian, J. Phys. Chem. C, 2010, 114, 10598-10605.

[14] C. Lertvachirapaiboon, A. Baba, S. Ekgasit, K. Shinbo, K. Kato, F. Kaneko, Sensor. Actuat. B, 2017, 249, 39-43.

[15] K. M. See, F. C. Lin, J. S. Huang, Nanoscale, 2017, 9, 10811-10819.

[16] X. Yi, W. Chen, G. Bertoni, I. Kriegel, X. Mo, N. Li, M. Prato, A. Riedinger, A. Sathya, L. Manna, Chem. Mater., 2011, 29, 1716-1723.

[17] G. M. Faccin, M. A. San-Miguel, J. Andres, E. Longo, E. Z. da Silva, J. Phys. Chem. C, 2017, 121, 7030-7036.

[18] Y. Sun, T. Xiong, Z. Ni, J. Liu, F. Dong, W. Zhang, W. K. Ho, Appl. Surf. Sci., 2015, 358, 356-362.

[19] B. Shi, H. Yin, J. Gong, Q. Nie, Appl. Surf. Sci, 2017, 419, 614-623.

[20] Y. Li, Z. Liu, Y. Wu, J. Chen, J. Zhao, F. Jin, P. Na, Appl. Catal. B, 2018, 224, 508-517.

[21] Q. Wang, J. Huang, H. Sun, K. Q. Zhang, Y. Lai, Nanoscale, 2017, 9, 16046-16058.

[22] J. Wang, L. Tang, G. Zeng, Y. Deng, H. Dong, Y. Liu, L. Wang, B. Peng, C. Zhang, F. Chen, Appl. Catal. B, 2018, 222, 115-123.

[23] C. Zhu, C. Liu, Y. Zhou, Y. Fu, S. Guo, H. Li, S. Zhao, H. Huang, Y. Liu, Z. Kang, Appl. Catal. B, 2017, 216, 114-121.

[24] X. Xu, Z. Bao, W. Tang, H. Wu, J. Pan, J. Hu, H. Zeng, Carbon, 2017, $121,201-208$.

[25] Y. Liu, G. Zhu, J.Z. Gao, M. Hojamberdiev, H. Luo, R. Zhu, X. Wei, P. Liu, J. Alloys Compd., 2016, 688, 487-496.

[26] T. Wang, X. Liu, C. Ma, Z. Zhu, Y. Liu, Z. Liu, M. Wei, X. Zhao, H. Dong, P. Huo, C. Li, Y. Yan, J. Alloys Compd., 2018, 752, 106-114.

[27] O. Moradlou, Z. Rabiei, A. Banazadeh, J. Warzywoda, M. Zirak, Appl. Catal. B, 2018, 227, 178-189.

[28] J. Jin, S. Zhu, Y. Song, H. Zhao, Z. Zhang, Y. Guo, J. Li, W. Song, B. Yang, B. Zhao, ACS Appl. Mater. Interfaces, 2016, 8, 27956-27965.

[29] D. Xu, Y. Hai, X. Zhang, S. Zhang, R. He, Appl. Surf. Sci., 2016, 400, 530-536.

[30] E. I. Vovk, A. V. Kalinkin, M. Y. Smirnov, I. O. Klembovskii, V. I. Bukhtiyarov, J. Phys. Chem. C, 2017, 121, 17297-17304.

[31] H. Li, X. He, Z. Kang, H. Huang, Y. Liu, J. Liu, S. Lian, C. H. A. Tsang, X.
Yang, S. T. Lee, Angew. Chem. Int. Ed., 2010, 49, 4430-4434.

[32] X. F. Meng, Y. Zhuang, H. Tang, C. H. Lu, J. Alloys Compd., 2018, 761, $15-23$.

[33] H. Yu, Y. Zhao, C. Zhou, L. Shang, Y. Peng, Y. Cao, L. Z. Wu, C. H. Tung, T. Zhang, J. Mater. Chem. A, 2014, 2, 3344-3351.

[34] C. Hu, Y. Liu, J. Qin, G. Nie, B. Lei, Y. Xiao, M. Zheng, J. Rong, ACS Appl. Mater. Interfaces, 2013, 5, 4760-4768.

[35] X. Wang, L. Cao, F. Lu, M. J. Meziani, H. Li, G. Qi, B. Zhou, B. A. Harruff, F. Kermarrec, Y. P. Sun, Chem. Commun., 2009, 3774-3776.

[36] Q. Q. Liu, J. Y. Shen, X. F. Yang, T. R. Zhang, H. Tang, Appl. Catal. B, 2018, 232, 562-573.

[37] G. A. M. Hutton, B. C. M. Martindale, E. Reisner, Chem. Soc. Rev., 2017, 46, 6111-6123.

[38] X. Liu, X. Wei, Y. Xu, H. Li, K. Lu, K. Wang, Y. Yan, Nano, 2017, 12, 1750024 .

[39] Z. Chen, X. Jiang, C. Zhu, C. Shi, Appl. Catal. B, 2016, 199, 241-251.

[40] J. Wang, D. Song, L. Wang, H. Zhang, H. Zhang, Y. Sun, Sensor. Actuat. $B, \mathbf{2 0 1 1}, 157,547-553$.

[41] Y. Liu, G. Zhu, J. Gao, M. Hojamberdiev, R. Zhu, X. Wei, Q. Guo, P. Liu, Appl. Catal. B, 2017, 200, 72-82.

[42] J. Yu, M. Jaroniec, Appl. Surf. Sci., 2017, 391, 71-71.

[43] F. Petronella, A. Truppi, C. Ingrosso, T. Placido, M. Striccoli, M. L. Curri, A. Agostiano, R. Comparelli, Catal. Today, 2017, 281, 85-100.

[44] W. Liu, J. Shen, Q. Liu, X. Yang, H. Tang, Appl. Surf. Sci., 2018, 462, 822-830.

[45] T. Weller, L. Specht, R. Marschall, Nano Energy, 2017, 31, 551-559.

[46] Y. Zhang, L. L. Han, C. Wang, W. H. Wang, T. Ling, J. Yang, C. Dong, F. Lin, X. W. Du, ACS Catal., 2017, 7, 1470-1477.

[47] D. Gu, Y. Qin, Y. Wen, T. Li, L. Qin, H. J. Seo, J. Alloys Compd., 2016, 695, 2224-2231.

[48] D. G. Li, S. H. Chen, S. Y. Zhao, X. M. Hou, H. Y. Ma, X. G. Yang, Appl. Surf. Sci, 2002, 200, 62-67.

[49] W. Liu, J. Shen, X. Yang, Q. Liu, H. Tang, Appl. Surf. Sci., 2018, 456, 369-378.

[50] X. Wang, R. Yu, K. Wang, G. Yang, H. Yu, Chin. J. Catal., 2015, 36, 1211-2218.

[51] F. Chen, H. Yang, W. Luo, P. Wang, H. Yu, Chin. J. Catal., 2017, 38, 1990-1998.

[52] T. Leshuk, R. Parviz, P. Everett, H. Krishnakumar, R. A. Varin, F. Gu, 
ACS Appl. Mater. Interfaces, 2013, 5, 1892-1895.

[53] C. S. Hong, Y. Wang, B. Bush, Chemosphere, 1998, 36, 1653-1667.

[54] Z. Zhu, P. Huo, Z. Lu, Y. Yan, Z. Liu, W. Shi, C. Li, H. Dong, Chem. Eng. J., 2018, 331, 615-625.

[55] Z. Zhu, Y. Yu, H. Dong, Z. Liu, C. Li, P. Huo, Y. Yan, ACS Sustainable
Chem. Eng., 2017, 5, 10614-10623.

[56] J. Qin, H. Zeng, Appl. Catal. B, 2017, 209, 161-173.

[57] Y. Guo, J. Zhang, D. Zhou, S. Dong, J. Mol. Liq., 2018, 262, 194-203.

[58] Z. Zhang, S. Lin, W. Cui, X. Li, H. Li, Mater. Lett., 2019, 234, 264-268.

\title{
等离子共振效应的 $\mathrm{Ag}$ 纳米颗粒修饰生物炭点 $/ \mathrm{Bi}_{4} \mathrm{Ti}_{3} \mathrm{O}_{12}$ 纳米片复合材料的 制备及其光催化性能
}

\author{
汪 涛, c, 刘锡清 ${ }^{\mathrm{a}, \mathrm{b}}$, 门秋月 ${ }^{\mathrm{a}, \mathrm{c}}$, 马长畅, , ,*, 刘 洋 ${ }^{\mathrm{c}, \mathrm{d}}$, 马 威, e, 刘 志, \\ 魏茂彬 ${ }^{\mathrm{c}, \mathrm{d}}$, 李春香 ${ }^{\mathrm{a}, \mathrm{c}}$, 间永胜 ${ }^{\mathrm{a}, \mathrm{c}, *}$ \\ a江苏大学化学与化工学院, 江苏镇江 212013 \\ b 江苏大学材料科学与工程学院, 江苏镇江 212013 \\ c 江苏大学绿色化学与化工研究院, 江苏镇江212013

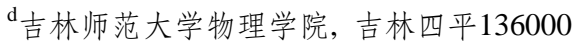 \\ e 江苏联合化工有限公司，江苏镇江 212212 \\ f辽宁师范大学化学与化工学院, 辽宁大连116029
}

摘要: 众所周知, 能源危机和环境污染是当前人们所面临的巨大难题和挑战, 因此寻找或开发一种高新的技术解决上述难 题尤为重要. 近年来, 基于半导体的光催化技术被广泛应用于能源制备和环境污染物去除领域, 该技术通过直接转化太阳 能为化学反应所需的能量来产生催化作用, 使周围的氧气或水分子激发成活性物质, 进而进行催化反应, 且同时催化材料 自身不受损耗, 被认为是一种高效、安全的环境友好型技术.

$\mathrm{Bi}_{4} \mathrm{Ti}_{3} \mathrm{O}_{12}$ 是一种物理化学性质稳定、环境友好型的半导体材料, 也是当前研究较多的一类铋系半导体光催化材料. 然 而, 纯相的 $\mathrm{Bi}_{4} \mathrm{Ti}_{3} \mathrm{O}_{12}$ 纳米材料自身电子分离效率低且可见光响应范围窄, 严重限制了其在光催化领域的应用. Ag纳米颗粒 具有等离子共振效应, 可以形成强的电场作用, 从而增强光的利用和电子-空穴对的产生. 碳点(CDs)是一类表面基团丰富、 具有独特光物理性质的纳米级碳材料. 碳点修饰的半导体光催化剂具有良好的稳定性和光催化活性. 因此, 制备 $\mathrm{Ag} / \mathrm{CDs} / \mathrm{Bi}_{4} \mathrm{Ti}_{3} \mathrm{O}_{12}$ 复合光催化剂可以有效扩宽 $\mathrm{Bi}_{4} \mathrm{Ti}_{3} \mathrm{O}_{12}$ 的光吸收范围, 增强电子-空穴对的分离效率, 从而提高光催化活性.

本文利用竹子作为碳源, 通过简单的水热法合成碳点, 以熔盐法合成 $\mathrm{Bi}_{4} \mathrm{Ti}_{3} \mathrm{O}_{12}$ 纳米片, 用简单的物理混合法将碳点修 饰在 $\mathrm{Bi}_{4} \mathrm{Ti}_{3} \mathrm{O}_{12}$ 表面, 再通过光沉积法将 $\mathrm{Ag}^{+}$还原在 $\mathrm{CDs} / \mathrm{Bi}_{4} \mathrm{Ti}_{3} \mathrm{O}_{12}$ 的表面, 从而制备出 $\mathrm{Ag} / \mathrm{CDs} / \mathrm{Bi}_{4} \mathrm{Ti}_{3} \mathrm{O}_{12}$ 复合光催化剂. 以 10 $\mathrm{mg} / \mathrm{L}$ 的四环素水溶液作为目标污染物, 测试光催化剂在可见光下对目标污染物的降解能力. 采用X射线衍射(XRD)、傅里 叶红外光谱(FT-IR)、透射电镜(TEM)、扫描电镜(SEM)、苂光光谱(PL)和光电流等表征方法分析了催化剂的结构特征、微 观形貌和光电性质等. XRD分析表明 $\mathrm{Bi}_{4} \mathrm{Ti}_{3} \mathrm{O}_{12}$ 材料被成功合成, 在CDs和 $\mathrm{Ag}$ 纳米颗粒进行修饰后未改变 $\mathrm{Bi}_{4} \mathrm{Ti}_{3} \mathrm{O}_{12}$ 的晶型结 构. XPS和EDS mapping的结果均表明复合材料由 $\mathrm{Ag}, \mathrm{C}, \mathrm{Bi}, \mathrm{Ti}$ 和 $\mathrm{O}$ 元素组成, 说明 $\mathrm{Ag} / \mathrm{CDs} / \mathrm{Bi}_{4} \mathrm{Ti}_{3} \mathrm{O}_{12}$ 复合光催化剂成功制 备. UV-vis DRS 结果表明, $\mathrm{Ag}$ 和 CDs 的修饰扩宽了 $\mathrm{Bi}_{4} \mathrm{Ti}_{3} \mathrm{O}_{12}$ 的可见光吸收范围. 苂光光谱和光电流结果也证明了 $\mathrm{Ag} / \mathrm{CDs} / \mathrm{Bi}_{4} \mathrm{Ti}_{3} \mathrm{O}_{12}$ 复合光催化剂具有更好的光响应能力和电子分离效率. 光催化性能测试最终证实 $\mathrm{Ag} / \mathrm{CDs} / \mathrm{Bi}_{4} \mathrm{Ti}_{3} \mathrm{O}_{12}$ 复合 光催化剂在可见光下具有良好的催化降解能力. 循环实验说明 $\mathrm{Ag} / \mathrm{CDs} / \mathrm{Bi}_{4} \mathrm{Ti}_{3} \mathrm{O}_{12}$ 复合光催化剂具有很好的稳定性, 是一种 具有潜力的催化材料.

用不同捕获剂进行了自由基捕获实验, 研究了 $\mathrm{Ag} / \mathrm{CDs} / \mathrm{Bi}_{4} \mathrm{Ti}_{3} \mathrm{O}_{12}$ 复合光催化剂的催化机理, 结果证实超氧自由基和空 穴在光催化过程中起主要作用, 羟基自由基也部分参与反应. 总之, 将碳点、 $\mathrm{Ag}$ 纳米颗粒与 $\mathrm{Bi}_{4} \mathrm{Ti}_{3} \mathrm{O}_{12}$ 结合制备的 $\mathrm{Ag} / \mathrm{CDs} / \mathrm{Bi}_{4} \mathrm{Ti}_{3} \mathrm{O}_{12}$ 复合光催化剂具有良好的光催化性能, 该工作为相关材料的制备和光催化研究提供了理论依据. 关键词: 2D材料; 等离子共振; 协同效应; 碳点; 电子缓冲

收稿日期: 2018-12-06. 接受日期: 2019-02-08. 出版日期: 2019-06-05.

*通讯联系人. 电话/传真: (0511)88791108; 电子信箱: yys@mail.ujs.edu.cn 基金来源：国家自然科学基金(U1510126, 21676115); 江苏省自然科学基金(BK20180884).

本文的电子版全文由Elsevier出版社在ScienceDirect上出版(http://www.sciencedirect.com/science/journal/18722067). 